\title{
Essentiality of Management of Facilities and Infrastructure toward a Number of Students of Early Years Institution
}

\author{
Hanif Alkadri \\ Faculty of Education, Universitas Negeri Padang \\ Padang, Indonesia \\ hanifalkadri78@gmail.com \\ Tia Ayu Ningrum \\ Faculty of Education, Universitas Negeri Padang \\ Padang, Indonesia
}

\author{
Yulianto Santoso \\ Faculty of Education, Universitas Negeri Padang \\ Padang, Indonesia \\ Hade Afriansyah \\ Faculty of Education, Universitas Negeri Padang \\ Padang, Indonesia
}

\begin{abstract}
This article aims to describe essenciality of management of facilities and infrastructure toward a number of student of early childhood education (ECE). This article examine one of the oldest Al-Quran ECE in Padang City, Amal Saleh ECE. This article is a qualitative research based on observation for two years. To validate of data, researchers have done triangulation. The result showed that facilities and infrastructure is very important to attract the public interest. So the condition of facilities and infrastructure influence toward a number of student each year. When the condition of educational facilities and institutions of ECE is poor and uncomplete, so it will be effect toward a number of school student. So, the government and the aothorities should be participated to help to improve the facilities and infrastructures of ECE. It influence to the large number of students in ECE.
\end{abstract}

Keywords-Al-qur'an ECE; facilities and infrastructures; number of student

\section{INTRODUCTION}

Kindergarten is one of the early childhood education (ECE) units which is important to be managed by all components of education well. That's because kindergarten plays an important role in the development of students during the golden years. Besides paying attention to the object of education objectives, it is also important to pay attention how to maintain existence of educational units of ECE in order to run well and keep growing.

The function of ECE as an educational unit institution is very important to shape the character of the student. One of the society needs for today is the educational institutions that instilling the values of character and Islam to students. This is the background of the birth of kindergarten and Al-Qur'an ECE.

The problems that exist now are about the components in the learning process implementation in kindergarten that is not managed well. Such as, the welfare of educators which is not up tu standard, facilities and infrastructures are incomplete according to the student needs, then according to one of ECE assessor in West Sumatera is also known that other problems that exist are the management of ECE that are not run properly.

The problems of early childhood education are also delivered by the chairman of the Association of Indonesian Early Childhood Educators, Netti Herawati, she state that there are eight problems in the world of child education, especially early childhood (ECE). Teacher education level is only 23.06 percent from S1 degree. Meanwhile, according to the National Standards of Education, the teachers should be both Formal and Non Formal ECE minimal S1 ECE / Psychology / Education. "Second, the issue of the quality of the Program and the institution of early childhood and still one-third of children aged 3-6 years who have not received the current ECE services, family involvement that has not been in line with and together with the ECE.

Another problem can be seen in Al-qur'an Kindergarten, the First Kindergarten in Padang city. Kindergarten Al-qur'an at the beginning is really interested by public. But now, it has the problem with the number of students which is very small, just 6 students.

This is inversely related to the interests, needs and culture of Minang people who want a school with Islamic nuances. Additionally, according to Mardiati (2015) state that the education of early childhood which has Islamic nuances is very important and the educational policy makers have to support the inculcation of Islamic basic values applicable at the level of early childhood education in material and non materil. And the purpose of the implementation of religious values in kindergarten is to realize the generation of noble character, strong faith and knowledge [1].

[2] In his research said that which plays an important role in increasing the number of students in educational institutions is customer service. And the last research about number of 
outcome is about significant relationships between child-staff ratios and child outcomes construed broadly [3].

The problems of early childhood need to be arranged in order to be resolved properly, managing all related components effectively. The aim is to implement effective education at the level of ECE units based on Al-qur'an. To be able to carry out good management, it is necessary to identify the things that cause it. For this reason this research wants to reveal the cause of the number of students in Al-qur'an Kindergarten First Padang city is decreasing. So that, reseacher must reseach about essentiality of management of facilities and infrastructure toward a number of student of early years institution.

\section{METHOD}

The research approach in this article is qualitative. To obtain the data which is really accurate base on reality in the field, validation or checking the validity of the data is done by triangulation of data, that is the use of variation of sources in collecting data [4]. In addition, triangulation in this study was also conducted by triangulation of data (triangulation data), triangulation of researchers (investigator triangulation), triangulation theory and methodological triangulation [4].

Analysis data is done as a systematic process since the search and compilation of interview transcripts, field notes, and other materials or resources have been collected to improve understanding and enable researchers to present something that has been discovered during the study [5].

Research data is reduced by performing abstractions containing the core summary [6]. The activity of collecting and analyzing the data essentiality of management of facilities and infrastructure. Toward a number of student of early years institution .Researchers move between four axes, moving back and forth between reduction activities, presentation and conclusions as described by Miles and Huberman [6].

\section{RESULTS AND DISCUSSION}

Based on observations conducted from June 2015 to June 2017 in one of the institutions Elder education is known that the importance of school facilities and infrastructure in determining the number of students. The results of this study illustrate that the development of the number of students the last 10 years is reduced. Then the role of facilities and infrastructure is very important to attract the public so that the number of students is not reduced.

Based on the results of research was known that the Kindergarten Al-qur'an Amal Saleh stood in 1986. Kindergarten Al-qur'an Amal Saleh is one of the early childhood schools Al-qur'an in the city of Padang. This school is the first educational institution to have a policy of using hijab for teachers and their students.

In the beginning, the Kindergarten of Al-qur'an Amal Saleh has many enthusiasts. This is because the policies of the curriculum of Al-qur'an applied and the implementation of learning also take into account the rules of Islam, such as: the use of hijab for all students and teachers. Based on the data obtained the last 10 years it is known that the development of the number of students of Al-qur 'Amal Saleh Kindergarten decreased. This can be seen from the graph below. This graph illustrates that since 2009 the number of kindergarten students has decreased. Then in 2014 the number of kindergarten students has decreased enormously, from 25 students in 2013 to 15 students in 2014 .

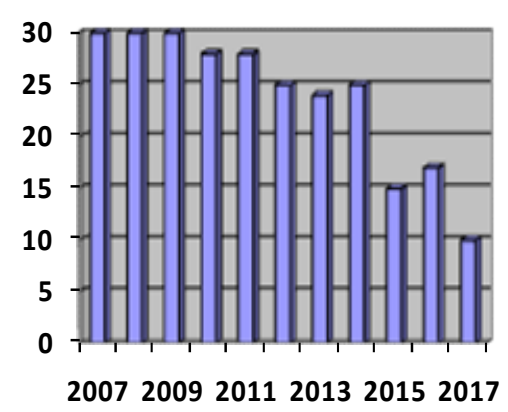

Fig. 1. Graph of the development of the number of students of Kindergarten Al-qur' and Amal Saleh

In 1986, facilities and facilities The infrastructure owned by TK Al-qur' and Amal Saleh can compete with other ECE Ordinary educational institutions. However, after the development of the era, the number of kindergartens in the city of Padang more and more standing with better facilities and complete. While the facilities and infrastructure of Kindergarten Al-qur`an Amal Saleh is never reconstructed.

Nowadays, besides the condition of facilities and infrastructure of Kindergarten of Al-qur'an Amal Saleh which are not reconstruct and completed, the facilities and infrastructure of this kindergarten are also many in bad condition. It can be seen from the roof of a leaking school room, a broken attic, kindergarten window that has been shifted and will not be locked. And for educational game tools (APE) are also incomplete and never update. Then added more sanitation clogged and the construction of a laundri next to the kindergarten building so the water does not flow smoothly.

In the graph above shows that, in the year 2014 there is a decline in the number of students very much. This is in line with conditions where TK buildings often flood because sanitation is not smooth. Then in 2017 also the number of students has decreased, this is because this year is being done building repairs on a large scale. So when the process of admission of new students, the condition of the building in the repair period. That is why the number of students is reduced. 
Meanwhile, according to informants, for ECE institutions, facilities and infrastructure is very important to attract the interest of the community. The community will be more interested in sending their children to schools that have good and complete facilities and infrastructures. This is seen when, there are several prospective parents of students who will enter the child to Kindergarten Amal Saleh every year, since facilities facilities and school infrastructure that many are damaged, they cancel to send their children in kindergarten Amal Saleh.

Based on the results of research known that the facilities and infrastructure affect the number of students. As stated by Megasari [7], that inadequate facilities and infrastructure will hinder the recruitment of new students. Similarly, good facilities and infrastructure and interesting will be a sympathetic community to continue their children's education to enter the educational institution.

The above statement explains that facilities and infrastructure are important in the student recruitment process where the process determines the number of students. For that the facilities and infrastructure needs to get special attention. It is appropriate that sustainably stated (2015) in his research that should further improve coordination and maximize the budget for the procurement of facilities and infrastructure so that schools are more advanced for the future. Conclusions and Recommendations School facilities and infrastructure play an important role in attracting students. The condition of facilities and infrastructure of kindergarten Amal Saleh unfavorable give influence to the number of students who want to go to school. For this reason the government and the parties who have the authority to help in improving the school facilities. The school should also be able to establish good communication and relationships with the public, whether it is the government, the surrounding community or other parties that can help provide material and non material assistance.

\section{CONCLUTION}

School facilities and infrastructure play an important role in attracting students. The condition of facilities and infrastructure of kindergarten Amal Saleh is not good to give effect to the number of students who want to enter school. For this reason the government and the parties who have the authority must help in improving facilities school. The school should also be able to establish good communication and relationships with the public, it also the government, the community around or other parties who can help provide material and non material assistance.

\section{ACKNOWLEDGMENT}

The authors would like to thank Dean of Faculty of Education, Universitas Negeri Padang for support of this study.

\section{REFERENCES}

[1] S. Sutarmin, "Cultivation of Basic Values of the Religion Humanist Childhood Early Childhood Family in an Integrated Islamic Kindergarten," J. Dev. Educ., vol. 2, 2014.

[2] Humena and H. Herliany, "Customer Service efforts in increasing the number of students in Ganesha Operation Branch of North Sulawesi," E-Journal Acta Diuma, vol. 5, 2016.

[3] M. Perlman, "Child-Staff Ratios in Early Childhood Education and Care Settings and Child Outcomes: A Systematic Review and MetaAnalysis," J. Plos One, vol. 12, 2017.

[4] S. Switzer, A Triangulated Data Approach to Assessing Academic English Learners. Chuncheon: Kangwon University, 2006.

[5] B. RC and B. SK, Qualitative Management Facility and Infrastructure at Early Childhood Education Research for Education, An Introduction to Theories and MethodsNo Title. Boston: Pearson Education, 2007.

[6] A. . Huberman, "Qualitative Data Analysis London: Sage Publication.Nawawi."History and Development of Pesantren"," $J$. Islam. Cult. Stud., vol. 4, 1984.

[7] R. Megasari, "Peningkatan Pengelolaan Sarana dan Prasarana Pendidikan Untuk Meningkatan Kualitas Pembelajaran di SMPN 5 Bukittinggi," Bahana Manaj. Pendidikan, J. Adm. Pendidika, vol. 2, pp. 636-648, 2014. 